\title{
Analysis of the Management and Costs Associated with Rearing Pregnant Dairy Heifers in the UK from Conception to Calving
}

\author{
Alana C. Boulton, Jonathan Rushton, D. Claire Wathes \\ Department of Production and Population Health, Royal Veterinary College, North Mymms, UK \\ Email: dcwathes@rvc.ac.uk
}

Received 31 August 2015; accepted 13 October 2015; published 16 October 2015

Copyright (C) 2015 by authors and Scientific Research Publishing Inc.

This work is licensed under the Creative Commons Attribution International License (CC BY). http://creativecommons.org/licenses/by/4.0/

(c) (i) Open Access

\begin{abstract}
Good management of the pregnant heifer is crucial to ensure that she is well grown and healthy and calves down easily before joining the milking herd. This study collected primary data on all aspects of heifer management on $101 \mathrm{UK}$ farms during heifer pregnancy from conception to calving including farm factors and associated costs of system inputs. A cost analysis workbook was developed to calculate the cost of rearing per heifer for each of the study farms. Associations between cost of rearing and farms factors were determined using linear regression and analysis of variance. Heifers had a mean age of conception of $509 \mathrm{~d}$ (range $365-700 \mathrm{~d}$ ) and an age at first calving of $784 \mathrm{~d}$ (range 639 - $973 \mathrm{~d}$ ). The mean total cost of rearing during pregnancy was $£ 450.36$ (range $£ 153.11$ to $£ 784.00$ ) with a mean daily cost of $£ 1.64$ (range $£ 0.56$ to $£ 2.86$ ). The inputs contributing the most to cost were feed (32.7\%), labour (23.8\%) and slurry disposal $(11.2 \%)$. Total purchased and homegrown feed and grazing contributed between $25.5 \%$ and $65.4 \%$ of total costs with a mean contribution of $43.6 \%$. The cost of rearing was lowest in spring calving herds and highest in all year round calving herds with intermediate values in autumn and multi block calving herds. The main variables influencing the cost were the number of days spent at grass, age at first calving, calving pattern, breed, herd size and region. Each extra day in age at first calving increased the mean cost of rearing during pregnancy by $€ 0.33 / \mathrm{d}$ whereas every extra day at grass reduced the cost by $€ 1.75 / \mathrm{d}$.
\end{abstract}

\section{Keywords}

Heifer, Cost Analysis, Pregnancy, Calving

How to cite this paper: Boulton, A.C., Rushton, J. and Wathes, D.C. (2015) Analysis of the Management and Costs Associated with Rearing Pregnant Dairy Heifers in the UK from Conception to Calving. Open Journal of Animal Sciences, 5, 474-485. http://dx.doi.org/10.4236/ojas.2015.54049 


\section{Introduction}

Rearing dairy heifers is the second largest annual expense of a dairy enterprise's production costs after feed, with no return on investment until the first lactation [1]. Recent expansion in the size of UK dairy herds has placed added pressure on existing labour and infrastructure resulting in minimal management of replacement stock. This is a concern as rearing heifers to enter the milking herd successfully at the optimal age and size requires careful attention to detail particularly in the areas of nutrition, reproduction and health [1]-[3]. Failure to control these aspects of rearing adequately is likely to contribute to both high levels of wastage and a wide spread in age at first calving (AFC) [4] [5]. Achieving a consistent AFC of around 23 - 25 months for all animals is beneficial as it reduces the total costs of rearing by minimising the time that heifers are kept within the replacement herd and the numbers of replacement animals needed to maintain herd size [3] [6]. There is also an increasing body of evidence showing that calving at 2 years of age increases the likelihood of completion of first lactation and overall length of survival in the herd [1] [3] [7] [8].

During the period from conception to calving, available energy must not only be partitioned into metabolic functions and growth of the dam but also into the maintenance of the growing fetus. Physical maturity in dairy cows is not reached until about the end of the third lactation [9]. The pre-natal period is therefore critically important not just for the dam but also for the future health and productivity of her own offspring. Depending on the stage of gestation and the duration and severity of the period of undernutrition, this can decrease calf birth weight and alter postnatal growth trajectories and carcass quality [10]-[13]. Inadequate maternal nutrition during late pregnancy can also affect the absorption capacity of the calf, reducing passive transfer of immunoglobulins from colostrum and thereby increasing the risk of enteric and respiratory disease in newborn calves [14]. Apart from nutrition, other stressors experienced during gestation can arise due to poor husbandry techniques, environmental conditions such as heat or cold stress, poor health of the dam and difficult births [15].

It is important that the heifer has reached an adequate body weight (ideally $90 \%$ as a proportion of mature body size) and frame size by the time she calves [16]. This affects the incidence of dystocia which may occur in up to $50 \%$ of first calving heifers [17] [18]. Perinatal calf mortality is also considerably higher for primiparous dams, for example $11 \%$ compared with $4.6 \%$ in multiparous dams [17]. Nutritional management during rearing including pregnancy can also affect the subsequent milk production potential of replacement heifers although it is hard to separate the effects of growth rate, age and weight at calving (see review [3]). A meta-analysis of studies examining the effects of heifer growth rates concluded that first-lactation milk production increased with increasing body weight at calving [19]. On the other hand, a number of studies have reported that first lactation yields in dairy heifers are not reduced providing that the AFC is $\geq 23$ months and that the animals are sufficiently well grown at calving [8] [20]-[22].

Mortality rates in cattle from 6 months of age until calving are relatively low, with reported incidences of 7.4\% in British heifers [4], 4.1\% in French dairy heifers [23] but only $0.8 \%$ in all cattle of this age in Northern Ireland [24]. Major causes reported were respiratory disease (37\%) and gastrointestinal syndromes (22\%) [24]. Nevertheless, disease can have a major impact on growth rates and fertility. Grazed animals are exposed to Fasciola hepatica, Cooperia oncophora and Ostertagia ostertagi. Of particular concern are diseases which may cause loss of the pregnancy. In a previous study of $17 \mathrm{UK}$ farms we found that $2.7 \%$ of heifers initially confirmed in calf suffered from late embryonic/early fetal mortality while a further 1.5\% aborted between 188 - 257 days of pregnancy [2]. Neospora caninum is the most commonly diagnosed cause of cattle abortions in the UK; $7.2 \%$ of UK heifers examined tested seropositive for this disease and infected animals were 5.3 times more likely to abort than uninfected cattle [25]. Many other bacterial, viral, protozoan and fungal pathogens can cause fetal mortality and abortion in cattle including, for example, Leptospira spp., bovine herpesvirus 1 and bovine viral diarrhea virus [26]. Another important health challenge during heifer pregnancy is mastitis which can be costly due to the potential loss of affected quarters and possible abortion of the fetus. Risk factors for mastitis include fly control, nutrition, hygiene measures at calving, season, location of the herd and stage of pregnancy [27]-[29].

The aim of this study was to examine current heifer rearing practices in the UK and their associated costs during the heifer's pregnancy from conception to first calving.

\section{Materials and Methods}

\subsection{Farm Selection, Questionnaire and Data Collection}

A total of 101 dairy farms located in England, Scotland and Wales were recruited via industry extension services, 
farm consultancy groups, social media platforms and private veterinary groups. Information on costs and management associated with the periods from birth to weaning [30] and weaning to conception [31] have been reported previously. The farms were visited from March through August 2013. An extensive questionnaire recording details of heifer management was completed during an interview by a single researcher (Royal Veterinary College Ethics and Welfare Committee number 2013 1199). Survey questions relating to the period of time from conception to calving included; labour, type and characteristics of heifer housing, the availability of solid feeds including forage, grain mixtures, concentrates and by-products, details on turn-out and rehousing, disease occurrence and vaccination and health treatments. Input costs and farm factors relating to this period were also documented.

\subsection{Calculation and Analysis of Input Costs}

Accurate ages at conception were not always available as some farms used natural service with a bull on at least a proportion of their heifers, so the number of days spent in the period from conception to calving was taken as a fixed value of 274 days ( 9 months) for all farms. This figure was selected based on a study which examined the gestation length of Holstein cattle [32].

The cost of bedding and disinfection was calculated from the number of days heifers spent in their accommodation, stocking rate, the size of the housing unit, type of bedding used, cost per tonne of bedding material, how often the housing was mucked out and rebedded and whether the area was washed or disinfected before rebedding. If heifers were cubicle housed on mats, the cost of the mat was only apportioned to the heifer once during the rearing period even if they occupied multiple accommodation where mats were used for bedding.

To calculate the cost of feed, the type of forage, grain mixtures, supplements, concentrates and by-products were documented. The cost per tonne of the feed as well as quantity (kg fresh weight) and the number of days the feed was offered was also recorded. On farms where feed was offered ad libitum, estimated daily intake was taken from the literature based on breed and age. The average of figures were used if a range of quantities, costs or number of days fed was provided by the farmer. The length of time (if any) that a heifer was introduced to a transition or dry cow diet in the time immediately prior to calving was noted.

Grazing costs included the cost of fertilizer application, annual establishment costs of a five year ley, the opportunity cost of renting out the grazing land and contractor costs. Contractor costs included mowing, harvesting, bailing and wrapping three silage cuts. All of these costs were obtained from The Agricultural Budgeting and Costing Book [33] and DairyCo grassland management improvement programme [34]. Whether calving took place indoors or at grass was recorded to ensure that this period of time was included either in the cost of calving management (i.e. the costs associated with calving inside such as bedding and disinfection) or in the cost of grazing.

The cost of transporting heifers between different holdings was based on farm personnel visiting the holding once a day as per The Welfare of Farmed Animals (England) Regulations 2000 (S.I. 2000 No. 1870) Schedule 4, paragraphs 3 and 4 . If heifers were housed with a contract rearer then only the cost of the return journey to the home farm prior to calving was included in the calculation as the cost of the outward journey was included in the previous development period.

Vaccination, worming and ectoparasite treatment were recorded, with the cost of each being determined by the product used, the frequency of use and whether the treatment was administered by a health professional or by farm personnel. Where the cost of the treatment was not known, information from online veterinary pharmaceutical suppliers was used. On farms where the bodyweight of heifers was not determined prior to administration of the treatment, the recommended body weights for age and breed of the heifer were used to determine the quantity of treatment [35] [36].

The methodology used to calculate the cost of labour, building and equipment depreciation, electricity, free water consumption and slurry storage and soiled bedding costs are described in Boulton et al. [30] [31]. With reference to slurry storage, the volume of slurry produced per day per heifer during pregnancy was assumed to be 40 litres per day [33].

\subsection{Statistical Analysis}

A workbook was developed in Microsoft Office Excel 2010 to perform a cost analysis of individual farm data with STATA v12.1 (StataCorp, College Station, Texas, USA) used for statistical analysis. The data were exam- 
ined for normality and heteroskedacity using the Shapiro-Wilk test and the Breusch-Pagan/Cook Weisberg test respectively. Simple linear regression and analysis of variance were used to test for associations between farm factors and the cost of rearing and to test for differences between the means of categorical variables. If the plot of residuals against each of the continuous predictor variables failed then continuous variables were categorized. Explanatory variables were assessed for collinearity, with a score of $>0.8$ indicating high correlation between two variables [37]. Variables with $p$-values $<0.2$ in the univariate analysis were included in a multivariable analysis using forward stepwise selection starting with the variable with the highest $\mathrm{F}$ statistic and lowest $p$ value from the univariable analysis. The results of the ANOVA were used to determine the fit of the model. Tests for interactions between variables were also conducted.

\section{Results}

The average herd size in this study was 237 milking cows (range 10 to 1200 cows) of mostly black and white purebred and crossbred herds. Heifers in this study had a mean age at conception of 509 days, range 365 to 700 [31] with a mean and median age of calving of 784 days and 776 days (25.8 and 25.5 months) respectively (range 639 to 973 days). During the period from conception to calving most farms turned their heifers out to grass once they had been confirmed in-calf. On $76.2 \%$ of farms heifers had been moved to a separate holdings post-weaning and these were generally returned to the home farm around 3 weeks prior to calving. The contribution of each of the input costs to the total cost of rearing from conception to calving is summarized in Table 1 and Figure 1.

\subsection{Labour}

The mean cost of labour during gestation was $£ 109.56 \pm 57.82$ (range $£ 22.16$ to $£ 304.14, n=101$ ) with a median of $£ 97.76$ per heifer. Labour included mucking out, feeding, daily checks and health-related requirements.

\subsection{Dry Feed}

On a majority of farms, once heifers had been served and/or confirmed pregnant then feeding of concentrates such as rearer nuts was reduced to avoid excess weight gain prior to calving. The majority of farms (77/101) fed grass silage as the main staple of the diet, with total mixed ration (TMR) the next most common feed (11/101) during this period. On 36.6\% (37/101) of farms, heifers were fed a dry cow/transition diet 7 to 60 days preparturition. The most frequent time that farmers chose to change the diet was 21 days before calving. The cost of many of the components of the transition ration was much more expensive compared to a similar weight of silage or TMR (£400 tonne versus £25 tonne). The cost of homegrown or purchased feed (excluding grazed grass)

Table 1. Summary data of the contribution of each of the costs associated with the total cost per farm of rearing their pregnant heifers from conception to first calving.

\begin{tabular}{|c|c|c|c|c|}
\hline \multirow{2}{*}{ Inputs } & \multicolumn{4}{|c|}{ \% Contribution to total cost of rearing during pregnancy } \\
\hline & $\mathrm{n}^{*}$ & Mean & Range & Median \\
\hline Labour & 101 & $23.8 \pm 8.9$ & $7.1-49.2$ & 22.8 \\
\hline Bedding & 100 & $6.5 \pm 4.9$ & $0-21.2$ & 4.9 \\
\hline Disinfection & 34 & $0.1 \pm 0.3$ & $0-2.6$ & 0 \\
\hline Building depreciation & 100 & $2.0 \pm 0.9$ & $0-5.0$ & 1.8 \\
\hline Purchased and homegrown feed & 101 & $32.7 \pm 10.2$ & $12.5-59.4$ & 30.6 \\
\hline Grazing & 100 & $11.0 \pm 6.6$ & $0-39.1$ & 9.1 \\
\hline Machinery and equipment & 101 & $4.0 \pm 2.0$ & $0.4-10.4$ & 3.7 \\
\hline Water & 101 & $4.2 \pm 2.0$ & $1.1-13.9$ & 3.8 \\
\hline Vaccinations & 77 & $1.8 \pm 1.7$ & $0-9.3$ & 1.5 \\
\hline Worm control and ectoparasite treatment & 95 & $2.1 \pm 1.6$ & $0-11.5$ & 1.8 \\
\hline Slurry storage & 100 & $11.2 \pm 9.5$ & $0-30.8$ & 12.6 \\
\hline Electricity & 101 & $0.8 \pm 0.3$ & $0.01-1.6$ & 0.8 \\
\hline
\end{tabular}

*There were 101 farms in the study but not all farms used all the potential inputs which were assessed. 
for the period from conception to calving per heifer per day ranged from $£ 0.79$ to $£ 2.83$ ( $n=101$ ) with a mean and median cost per day of $£ 1.43 \pm 0.35$ and $£ 1.35$ respectively. The cost of feed per day was greater than $£ 1.00$ in $83 \%(84 / 101)$ of herds with $8 \%$ of herds having a feed cost per day of $>£ 2.00$. The mean cost of feed per heifer per day for the different calving patterns was $£ 1.30 \pm 0.10$ for spring calving herds, $£ 1.55 \pm 0.44$ for autumn calving herds, $£ 1.51 \pm 0.43$ for multi block calving herds and $£ 1.41 \pm 0.33$ for all year round (AYR) calving herds.

\subsection{Turnout and Grazing}

The mean number of days that heifers spent at grass from conception to calving was $172 \pm 35.8$ (range 91 to 274 days, median $=182.5$ days, $n=100$ ). Separated into calving pattern, spring born heifers spent on average 207 days at grass, autumn heifers 197 days, all year round born heifers were the lowest with a mean of 162 days and multi block herds turned heifers out to grass for 187 days. The mean cost of grazing per heifer was $£ 44.81 \pm$ 21.06 (range $£ 9.62$ to $£ 100.97, \mathrm{n}=100$ ) with a median of $£ 40.75$. The cost per day per heifer ranged from $£ 0.07$ to $£ 0.60$ with a mean of $£ 0.26 \pm 0.12$ (median $=£ 0.24, n=100$ ). Each extra day spent at grass during pregnancy reduced the total cost of rearing in this period by £2.20 (Figure 2) and the cost per day was similarly reduced.

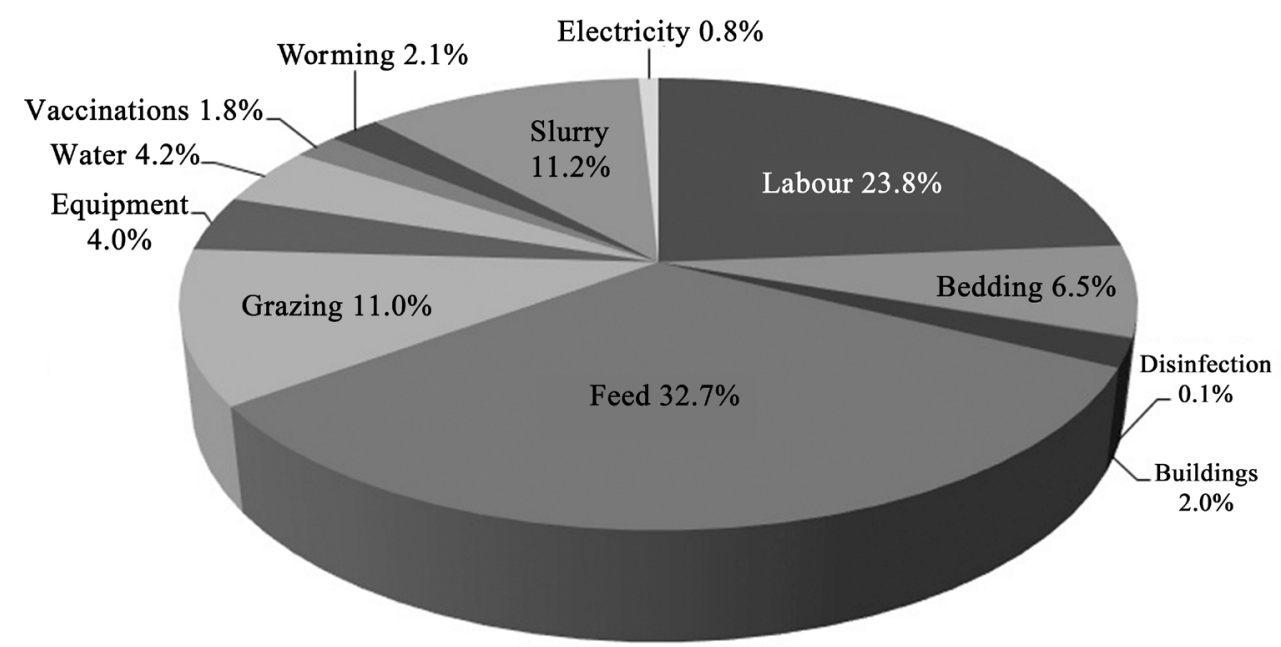

Figure 1. Contribution of input costs to total cost of rearing pregnant heifers from conception to first calving.

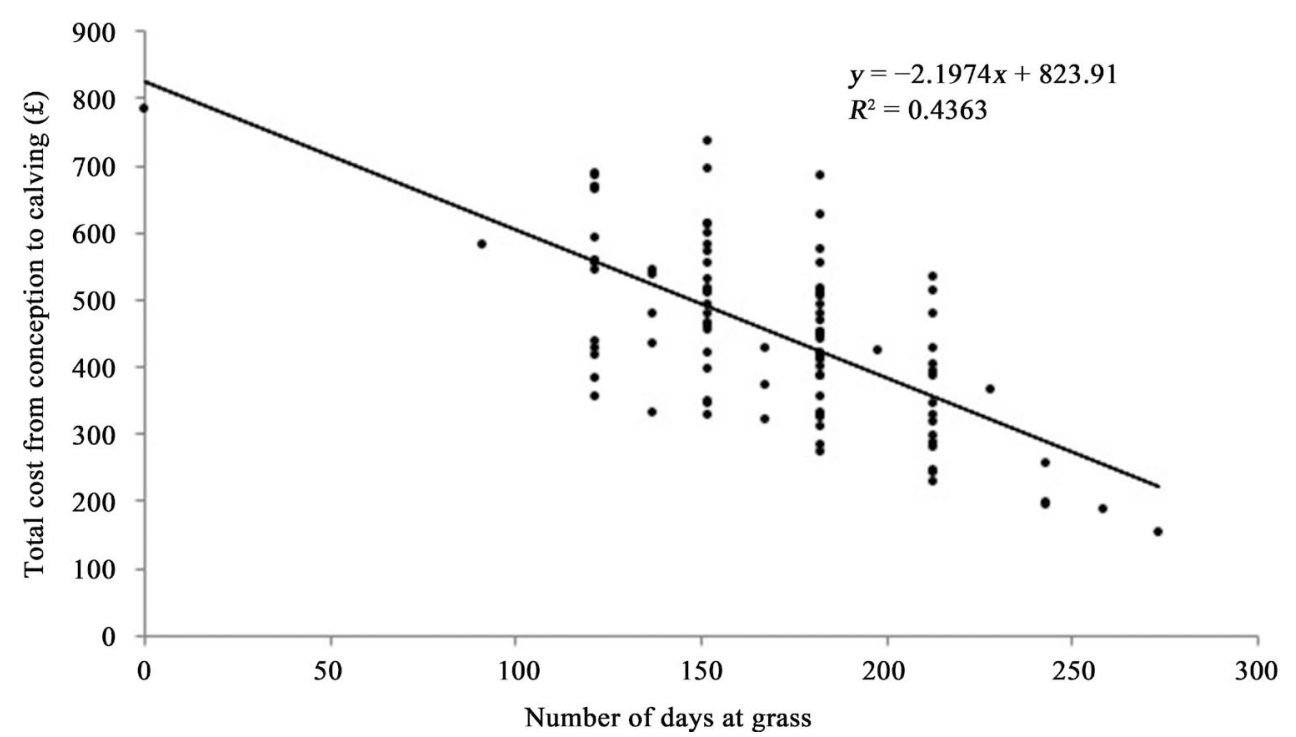

Figure 2. Regression analysis between the number of days that pregnant heifers spend at grass and the cost of rearing from conception to calving. Each symbol represents one farm, $n=101$. 


\subsection{Housing, Bedding and Slurry}

During this period heifers on a majority of farms (84/101) spent less than half of the gestation period (137 days) housed, with total time housed ranging from 0 to 274 days (i.e. the entire length of gestation). The mean and median values were $106 \pm 38.5$ and 92 days respectively $(n=100)$. One farm did not house their heifers for any time during this period as they turned out in February following insemination and calved heifers at grass. The number of heifers being housed in cubicles increased to 53 farms during this time with the mean area of housing allocated per heifer being $3.5 \mathrm{~m}^{2} \pm 2.1$ (range $2.5 \mathrm{~m}^{2}$ to $14.9 \mathrm{~m}^{2}$, median $=2.5 \mathrm{~m}^{2}, \mathrm{n}=100$ ). The remaining heifers were housed in groups ranging from 5 to 50 heifers, mostly on straw (46/47).

The mean cost of bedding per day during gestation was $£ 0.12 \pm 0.1$ (range $£ 0.01$ to $£ 0.40$, median $=£ 0.09$, $n$ = 95). Five farms did not have any bedding costs due to their heifers being housed on mats only. If mats had also been used in the period from weaning to conception then the cost of the mat had already been allocated to this earlier period. A total of 34 farms disinfected their housing when mucking out and rebedding. The disinfection cost for this period ranged from $£ 0.03$ to $£ 15.63$ with a mean of $£ 1.23 \pm 2.97$ (median $£ 0.20$ ). The cost of slurry storage and spreading of soiled bedding ranged from $£ 0.15$ to $£ 164.40$ with a mean of $£ 62.36 \pm 23.75$ (median = $£ 54.90, \mathrm{n}=100)$.

\subsection{Vaccinations, Worming and Ectoparasite Treatment}

Vaccinations were administered on 76.2\% (77/101) of farms during pregnancy. The most common diseases being vaccinated for were bovine viral diarrhoea virus (BVDV) (44/77), Leptospirosis (29/77) and infectious bovine rhinotracheitis (IBR) (27/77). Six farms administered the Rotavec Corona (MSD Animal Health, Milton Keynes, UK) vaccine to heifers before calving to raise antibodies in the dam. The cost of vaccinations ranged from $£ 0.80$ to $£ 24.80$ per heifer with a mean and median cost of $£ 9.62$ and $£ 8.43$ respectively $(n=77)$. Worming and ectoparasite treatment prior to or after turnout or at rehousing was practiced on 94\% (95/101) farms with a mean cost per heifer of $£ 9.05 \pm 6.83$ (range $£ 0.88$ to $£ 47.64$, median $=£ 7.08, n=95$ ). The parasites most commonly treated for were Dictyocaulus viviparous (lungworm) (77/95) and Fasciola hepatica (liver fluke) (26/95).

\subsection{Drinking Water and Electricity}

The mean cost of electricity per heifer during pregnancy was $£ 3.57 \pm 1.51$ (range $£ 0.01$ to $£ 10.00, n=101$ ) with a median of $£ 3.30$. Free access water cost $£ 0.06 \pm 0.02$ (range $£ 0.02$ to $£ 0.11$, median $=£ 0.06, n=101$ ) per heifer per day based on estimated bodyweight.

\subsection{Building and Equipment Depreciation}

The cost of building depreciation attributed to heifers during pregnancy ranged from $£ 1.95$ to $£ 23.82$ with a mean of $£ 9.10$ (median $=£ 8.63, \mathrm{n}=100$ ). One farm was not included in the analysis as their pregnant heifers were never housed. The mean cost of maintenance and depreciation of equipment was $£ 17.91 \pm 11.44$ (range $£ 2.70$ to $£ 56.63$, median $=£ 15.08, \mathrm{n}=101$ ).

\subsection{Total Cost of Rearing from Conception to Calving}

The mean total cost of rearing from conception to calving was $£ 450.36 \pm 131.42$ (range $£ 153.11$ to $£ 784.00, \mathrm{n}=$ 101 ) with a median of $£ 447.31$. The greatest expense was feed (including purchased feed and homegrown forage but excluding grazing) at $32.7 \%$ with the second and third main expenses being labour (23.8\%) and slurry storage (11.2\%). Total purchased and homegrown feed and grazing contributed to between $25.5 \%$ and $65.4 \%$ of total costs with a mean contribution of $43.6 \% \pm 9.6$ (median $=42.9 \%, n=101)$. The mean daily cost of rearing during this period was $£ 1.64 \pm 0.47$, ranging from $£ 0.56$ to $£ 2.86$ (median $=£ 1.63, n=101$ ). The total cost of rearing pregnant heifers was lowest in spring calving herds with a mean of $£ 269.74 \pm 70.87$ and highest in AYR calving herds at $£ 492.69 \pm 111.25$. Autumn and multi block calving herds had mean total costs of rearing of $£ 327.18 \pm 138.42$ and $£ 408.28 \pm 79.58$ respectively (Figure 3 ). The cost of rearing from conception to calving tended to increase with increasing AFC although there was a large spread of values (Figure 4).

\subsection{Variables Influencing the Cost of Rearing from Conception to Calving}

The main variables influencing the cost of rearing heifers during pregnancy were age at first calving, the number 


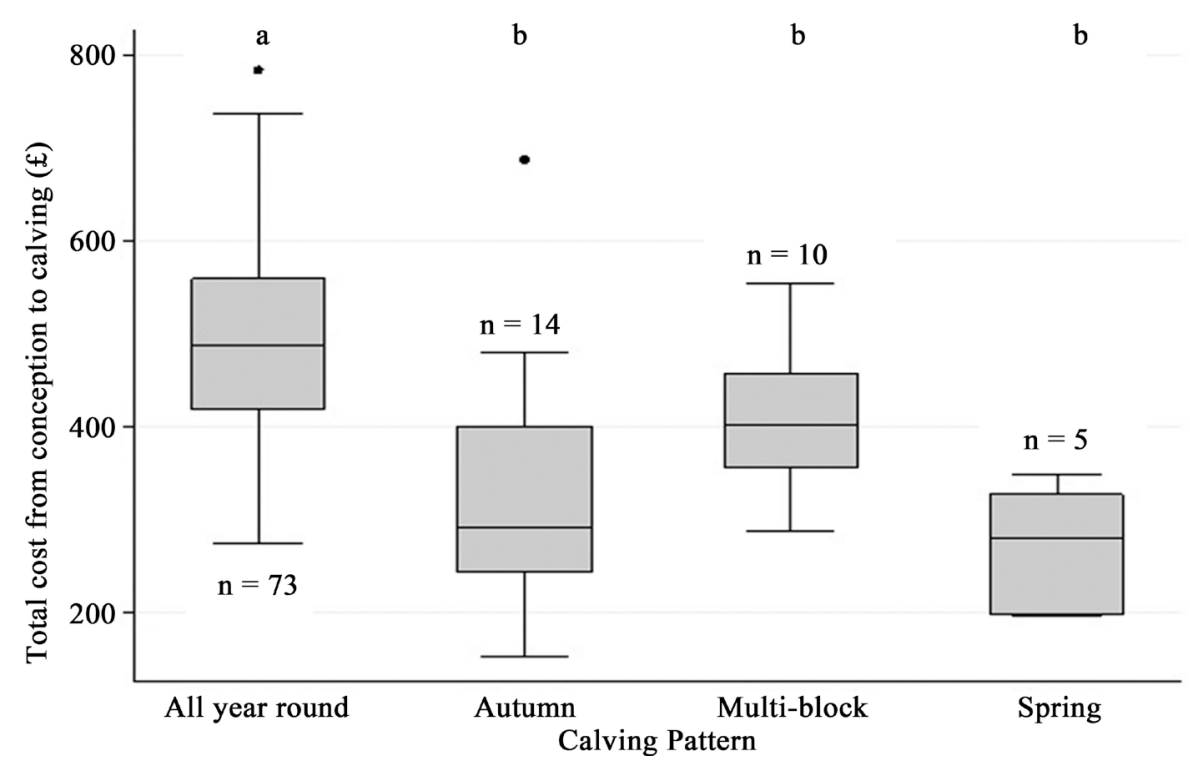

Figure 3. Box and whiskers plot showing the total cost of rearing pregnant heifers from conception to first calving for the four different calving patterns: $\mathrm{a}>\mathrm{b}, \mathrm{p}<0.05$.

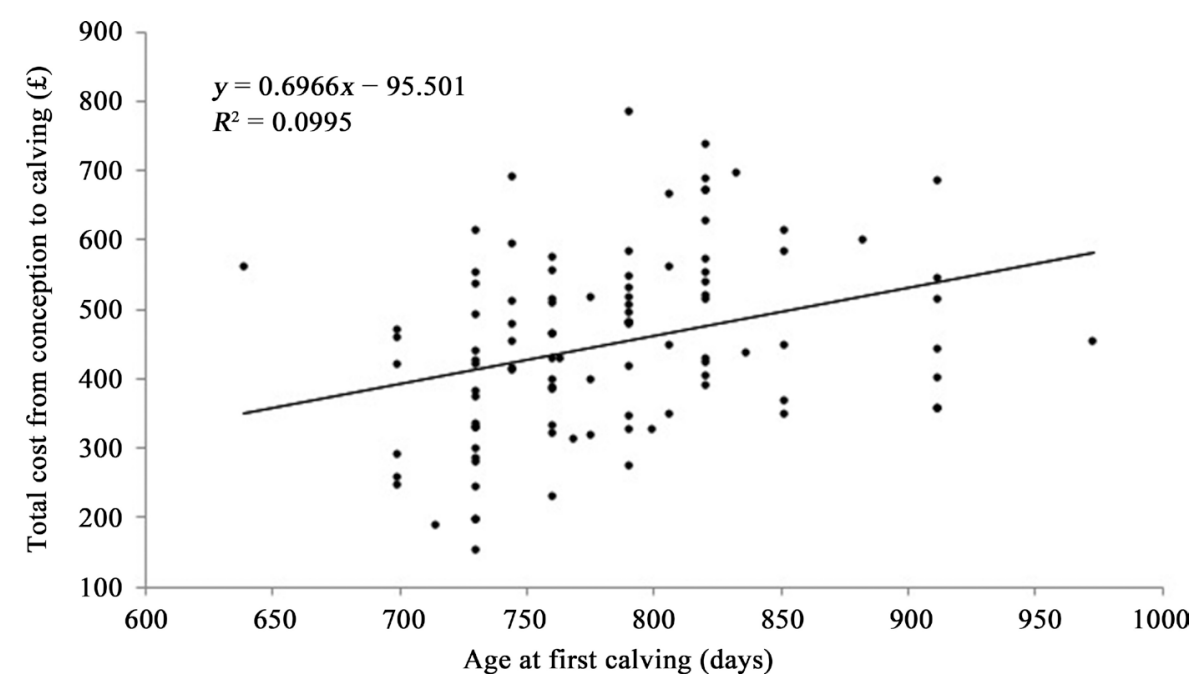

Figure 4. Regression analysis between the age at first calving (days) and the cost of rearing from conception to calving. Each symbol represents one farm, $n=101$.

of days spent at grass, breed, calving pattern, herd size and region. Together these accounted for $72.6 \%$ of the variation in the cost of rearing from conception to calving in the multivariable model with an $\mathrm{F}(23,77)$ statistic of 8.89 ( $p<0.0001$ ) (Table 2 and Table 3). Adjusting for the effect of calving pattern, breed, herd size and region, the mean cost of rearing during pregnancy increased by $£ 0.33$ for each extra day age at first calving and decreased by $£ 1.75$ for every extra day at grass. With respect to breed, purebred Holstein was taken as the base line. Holstein $\times$ herds had an increase in cost of rearing compared to Holstein herds (£35.77), while all other pure breeds, Holstein-Friesians and Friesian crosses were less expensive to rear during pregnancy. Of these, Jersey heifers were the cheapest by $£ 92.81$ compared to Holsteins. AYR calving was the most expensive calving pattern and the predicted reductions in cost of rearing on multi-block, autumn and spring calving systems were $£ 23.35$, £93.18 and £75.42 respectively. All herd sizes $>100$ had lower expenses of between $£ 96.14$ and $£ 157.01$ compared to herds with $<100$ milking cows. Taking east of England as the baseline, four of the nine UK regions had greater costs from conception to calving (Mid-West, South, Wales and North West) whereas four had lower rearing costs (Midlands, North, Scotland and South East). 
Table 2. The effect of different exposure variables on the total cost of heifer rearing during pregnancy assessed using one way ANOVA.

\begin{tabular}{ccccc}
\hline Variable $^{\#}$ & $\mathrm{df}$ & $\mathrm{F}$ & Prob $>\mathrm{F}$ & Adj R $^{2}$ \\
\hline Age at first calving & 1,99 & 10.93 & 0.0013 & 0.0904 \\
Enterprise type & 1,99 & 0.63 & 0.4297 & -0.0037 \\
Calving pattern & 3,97 & 14.02 & $<0.0001$ & 0.2808 \\
Breed & 5,95 & 2.47 & 0.0379 & 0.0684 \\
Region & 9,91 & 1.88 & 0.0643 & 0.0736 \\
Herd size & 4,96 & 4.73 & 0.0016 & 0.1297 \\
Culling rate \% & 5,95 & 1.03 & 0.4035 & 0.0016 \\
Calving rate \% & 5,95 & 0.97 & 0.4424 & -0.0017 \\
Stillbirth rate\% & 4,96 & 0.93 & 0.4508 & -0.0029 \\
First lactation yield & 5,95 & 1.49 & 0.2002 & 0.0239 \\
Herd lactation yield & 5,95 & 1.12 & 0.3556 & 0.0059 \\
bTB status & 1,99 & 0.59 & 0.4451 & -0.0041 \\
Days at grass & 1,99 & 76.63 & $<0.0001$ & 0.4306 \\
\hline
\end{tabular}

\#Age at first calving; enterprise type, classification of farms on their organic status; calving pattern, season(s) when the majority of the herd calved; breed, predominant breed in the herd; region, the location of the farm within the UK based on the dairy levy board groupings; herd size, number of cows in the milking herd including dry cows; culling rate, \% cows in the herd culled in the last 12 months; calving rate, \% cows in the herd calved in the last 12 months; stillbirth rate, \% calves born dead from the number of cows that calved in the last 12 months; first lactation and herd lactation yield, respective average yields (kg) from the most recent 305-day lactation records; bTB status, whether the farm was currently under movement restrictions; days at grass, number of days heifers spent grazing (not housed)

Table 3. Results of multivariable linear regression analysis of cost of rearing pregnant heifers from conception to first calving according to age at first calving, days at grass, breed, calving pattern, herd size and region.

\begin{tabular}{|c|c|c|c|c|c|c|c|c|}
\hline Variable & & $\mathrm{n}$ & Coefficient & Std. Error & $\mathrm{t}$ & $P>|t|$ & \multicolumn{2}{|c|}{$95 \%$ CI } \\
\hline Age at first calving & & 101 & 0.33 & 0.16 & 2.01 & 0.05 & 0.00 & 0.65 \\
\hline \multirow[t]{3}{*}{ Days at grass } & & 101 & -1.75 & 0.27 & -6.39 & $<0.0001$ & -2.29 & -1.20 \\
\hline & Baseline & 40 & \multicolumn{6}{|c|}{ Holstein } \\
\hline & Holstein Friesian & 29 & -11.07 & 20.93 & -0.53 & 0.599 & -52.75 & 30.62 \\
\hline \multirow{5}{*}{ Breed } & Holstein $\mathrm{x}$ & 13 & 35.77 & 28.14 & 1.27 & 0.208 & -20.27 & 91.81 \\
\hline & Friesian $\mathrm{x}$ & 4 & -62.68 & 50.48 & -1.24 & 0.218 & -163.19 & 37.84 \\
\hline & Other purebreds & 9 & -39.32 & 38.09 & -1.03 & 0.305 & -115.17 & 36.53 \\
\hline & Jersey & 6 & -92.81 & 38.34 & -2.42 & 0.018 & -169.15 & -16.47 \\
\hline & Baseline & 73 & \multicolumn{6}{|c|}{ All year round } \\
\hline \multirow{5}{*}{ Calving pattern } & Autumn & 14 & -93.18 & 29.99 & -3.11 & 0.003 & -152.91 & -33.45 \\
\hline & Multi block & 10 & -23.35 & 31.37 & -0.74 & 0.459 & -85.81 & 39.11 \\
\hline & Spring & 5 & -75.42 & 45.31 & -1.66 & 0.100 & -165.64 & 14.79 \\
\hline & Baseline & 12 & \multicolumn{6}{|c|}{0 to 99 cows } \\
\hline & 100 to 199 & 39 & -96.14 & 29.32 & -3.28 & 0.002 & -154.53 & -37.76 \\
\hline \multirow[t]{7}{*}{ Herd size } & 200 to 299 & 30 & -108.30 & 32.94 & -3.29 & 0.002 & -173.89 & -42.71 \\
\hline & 300 to 399 & 14 & -141.55 & 36.20 & -3.91 & $<0.0001$ & -213.63 & -69.47 \\
\hline & $\geq 400$ & 6 & -157.01 & 46.01 & -3.41 & 0.001 & -248.62 & -65.39 \\
\hline & Baseline & 5 & \multicolumn{6}{|c|}{ East } \\
\hline & Far West & 8 & 75.68 & 51.11 & 1.48 & 0.143 & -26.08 & 177.45 \\
\hline & Mid West & 8 & 0.94 & 52.02 & 0.79 & 0.434 & -62.65 & 144.52 \\
\hline & Midlands & 12 & -4.01 & 47.80 & -0.08 & 0.933 & -99.20 & 91.18 \\
\hline \multirow{6}{*}{ Region } & North & 14 & -4.46 & 45.31 & -0.10 & 0.922 & -94.68 & 85.77 \\
\hline & North West & 17 & 72.37 & 45.93 & 1.58 & 0.119 & -19.08 & 163.82 \\
\hline & Scotland & 10 & -7.63 & 51.83 & -1.15 & 0.883 & -110.82 & 95.57 \\
\hline & South & 4 & 62.55 & 58.98 & 1.06 & 0.292 & -54.89 & 179.99 \\
\hline & South East & 7 & -36.72 & 51.44 & -0.71 & 0.477 & -139.16 & 65.71 \\
\hline & Wales & 16 & 36.86 & 47.63 & 0.78 & 0.440 & -57.89 & 131.80 \\
\hline
\end{tabular}




\section{Discussion}

This is the last in a series of three papers which examined the economic costs of rearing heifers from birth to the point of first calving under different UK management systems. In this paper we have assessed the costs of rearing the heifer during her first pregnancy. Although published gestation lengths vary over a range 253 to 292 days, we have taken them as a fixed length of 274 days to simplify the calculations as precise gestation lengths were not known when natural service had been used. We also did not account for embryonic/fetal losses during pregnancy or abortions which are discussed below. The mean and median AFC in this study were 25.8 months and 25.5 months respectively. These are similar to values reported in two previous datasets obtained from English and Dutch dairy farms which had means AFCs of 25.5 and 25.4 months respectively [8] [38]. Having a low AFC of around 23 - 25 months reduces the total costs of rearing as the unprofitable period during which the heifer is kept within the replacement herd is minimized [3] [39]. We show here that even though gestation length was taken as a fixed length of time, the cost of rearing the pregnant heifer was $£ 0.33$ per day more for each extra day by which AFC increased.

The other key factor influencing the expense of maintaining the pregnant heifer was the amount of time spent at pasture, as the cost per animal decreased by $£ 1.75$ for every extra day at grass. The mean and median costs per animal per day of feeding indoors were $£ 1.43 \pm 0.35$ and $£ 1.35$ whereas for grazing animals these figures were only $£ 0.26 \pm 0.12$ and $£ 0.24$ respectively. Overall, purchased feed and homegrown forage contributed $32.7 \% \pm 10.2 \%$ to the total cost of rearing during gestation ranging from $12.5 \%$ to $59.4 \%$ between different farms. If the cost of grazing was added this increased to $43.6 \% \pm 9.6 \%$ (range $27.5 \%$ to $61.9 \%$ ). These figures are much lower than those reported by Heinrichs et al. [40] in their study on heifer rearing in the USA where feed accounted for on average $74.2 \%$ of total costs during gestation, ranging from $67.4 \%$ and $85.3 \%$. No grazing costs were given in the study or mention of time heifers spent at grass which could account for the large difference in costs if heifers were housed all year round. The American study also did not include other input costs such slurry storage and building and machinery depreciation and maintenance. Slurry storage was the third highest contribution to total cost in the present study (11.2\%). Other differences between the studies may relate to breed differences as in this study the costs of rearing smaller breeds such as Jersey were lower than for Holsteins, in part due to their lower feed requirements.

The mean cost per heifer of all feed during this period was $£ 196.50 \pm 56.31$ (range $£ 95.56$ to $£ 442.48$ ). In contrast, Promar International [41] estimated a total feed cost during pregnancy of approximately $£ 139$ but they only considered rearer concentrate which averages £250/tonne. Many farmers in our study introduced transitional diets during the last few weeks prior to calving, with many blends and feeds included in the transition diet averaging $£ 500 /$ tonne. DARDNI [42] estimated feed costs of $£ 161$ for autumn born heifers calving at 30 months of age and $£ 138.80$ for autumn born heifers calving at 24 months. The cost of feed was lower in spring born heifers calving at 24 and 27 months at $£ 128$ and $£ 104$ respectively. In our study the mean feed cost during this period for spring calving herds was $£ 145.18$ and for autumn calving herds $£ 165.12$, comparable with the DARDNI report. Both the DARDNI report and our study calculated similar costs of grazing in the second grazing season of $£ 42.00$ and $£ 44.36$ per heifer respectively. The difference in feed cost between spring and autumn calving herds is likely due to the length of time spent at grass during this period being 207 and 197 days respectively.

The amount of time that heifers spent housed during pregnancy ranged from 15 to 274 days with a mean of 106 days. Bedding and disinfection of heifer accommodation accounted for on average $6.5 \%$ and $0.1 \%$ of the total cost of rearing for this period respectively. This compares to a mean contribution of bedding of $3.4 \%$ (range $0 \%$ to $14.1 \%$ ) in the study be Heinrichs et al. [40]. The removal of slurry and soiled bedding contributed the most to the cost of housing at $11.2 \%$ of total costs, with electricity and building depreciation and maintenance contributing $0.8 \%$ and $2.0 \%$ respectively. More than half of the farms surveyed (52.5\%) used cubicle housing for pregnant heifers with the remainder of farms electing to group house heifers. During the period from conception to calving most farms turned heifers out to grass once confirmed in-calf, with heifers that are kept on separate holdings post-weaning being returned to the home farm around 3 weeks prior to calving. Preparing heifers for their first calving through good transition diet management and if necessary cubicle training reduces any possible health problems during early lactation and aids their assimilation into the milking herd.

After feed, labour was the next main expense with a mean contribution of $23.8 \% \pm 8.9 \%$ to the total cost. The large range in labour costs between farms (7.1\% and $49.2 \%)$ was mainly a result of variations in the number of heifers in the rearing herd and the number of staff caring for them. A large number of heifers with only a few 
members of staff responsible for their care resulted in a small labour cost being apportioned to each heifer. This also in large part explained the impact of herd size on heifer rearing costs which was greatest in herds with less than 100 milking cows. The lower value of labour input to total cost estimated by Heinrichs et al. [40] of 7.2\% (ranging from $1.8 \%$ to $11.2 \%$ ) was probably due to the higher contribution of feed to total cost in their study and the omission of some other input costs from the total, as discussed above.

The main health costs incurred during heifer pregnancy were for worming and ectoparasite treatments prior to or after turnout or at rehousing which were given on nearly all farms (94\%). A lower proportion of farms (76.2\%) administered at least one vaccination mainly for BVDV. Together these accounted for $3.8 \%$ of the total cost (range $0 \%$ to $12.1 \%$ ). This was again a higher proportion than in the study by Heinrichs et al. [40] which attributed $0.6 \%$ of total expenditure during this period to health costs (range of $0 \%$ to $2.3 \%$ ). We were unable within this survey to assess the prevalence of different infections known to impact on heifer growth and pregnancy maintenance. These include, for example, Fasciola hepatica, Neospora caninum and BVDV which all have a high current prevalence on UK farms [43]-[45]. We have however reported in a previous survey of 17 farms that $2.7 \%$ of heifers initially confirmed in calf suffered from late embryonic/early fetal mortality while a further 1.5\% aborted between 188 - 257 days of pregnancy [2]. Any animal losing her pregnancy early has to be inseminated again. The average cost of achieving an initial conception in our study was $£ 58.47$ [31] but heifer fertility falls as animals age [46] so the costs may be more in this subset of animals. Assuming that they do conceive again, the AFC is also inevitably increased and in our earlier study it was on average 32.2 months in the heifers which lost their initial pregnancy [2]. As we show here a cost of $£ 0.33$ per day for each extra day, this equates to about $£ 84$ if AFC is delayed from 24 to 32 months. In contrast heifers which abort late in gestation may start a lactation and so enter the milking herd at a relatively younger age. However there is no viable calf and milk production is likely to be compromised, so these factors again carry an adverse economic outcome.

Limitations of the study are the small numbers of non-black and white breeds and different calving pattern herds most especially spring block calving. A larger number of other purebreds and block calving herds would enable some of the parameters to be refined thus reducing the large ranges for many of the variables. However, this may not be representative of the current UK dairy population which is conventional, all year round calving with black and white genetics.

\section{Conclusion}

The cost of rearing the pregnant heifer varied greatly from $£ 153$ to $£ 784$ in the 101 herds included in this study, with a median of $£ 447$. The total cost was most strongly associated with the number of days at grass, AFC and the calving pattern of the herd. It was lowest in spring calving herds which maintained an AFC close to 24 months and kept their heifers at pasture for most of gestation. While farmers need to minimise unnecessary expenses it is also important for them to appreciate that the nutrition and health of the pregnant heifer affects not only her productivity and survival time within the dairy herd, but also that of the calf which she is carrying. It is therefore worthwhile to invest in sufficient feed to maintain heifer growth, to put in place preventative measures for diseases which can reduce growth and fertility and to ensure good transition management to minimise problems around first calving.

\section{Acknowledgements}

The authors thank all the dairy farmers who participated in the study. The work was co-funded by DairyCo and the BBSRC. This manuscript has been assigned the reference PPH_01097 by the RVC.

\section{References}

[1] Bach, A. (2011) Associations between Several Aspects of Heifer Development and Dairy Cow Survivability to Second Lactation. Journal of Dairy Science, 91, 3259-3267. http://dx.doi.org/10.3168/jds.2008-1030

[2] Brickell, J.S., Bourne, N., McGowan, M.M. and Wathes, D.C. (2009) Effect of Growth and Development during the Rearing Period on the Subsequent Fertility of Nulliparous Holstein-Friesian Heifers. Theriogenology, 72, 408-416. http://dx.doi.org/10.1016/j.theriogenology.2009.03.015

[3] Wathes, D.C., Pollott, G.E., Johnson, K.F., Richardson, H. and Cooke, J.S. (2014) Heifer Fertility and Carry over Consequences for Life Time Production in Dairy and Beef Cattle. Animal, 8, 91-104.

http://dx.doi.org/10.1017/S1751731114000755 
[4] Brickell, J.S., McGowan, M.M., Pfeiffer, D.U. and Wathes, D.C. (2009) Mortality in Holstein-Friesian Calves and Replacement Heifers in Relation to Body Weight and IGF-1 Concentration, on 19 Farms in England. Animal, 3, 11751182. http://dx.doi.org/10.1017/S175173110900456X

[5] Brickell, J.S. and Wathes, D.C. (2011) A Descriptive Study of the Survival of Holstein-Friesian Heifers Through to Third Calving on English Dairy Farms. Journal of Dairy Science, 94, 1831-1838. http://dx.doi.org/10.3168/jds.2010-3710

[6] Tozer, P.R. and Heinrichs, A.J. (2001) What Affects the Costs of Raising Replacement Dairy Heifers: A MultipleComponent Analysis. Journal of Dairy Science, 84, 1836-1844. http://dx.doi.org/10.3168/jds.s0022-0302(01)74623-1

[7] Hultgren, J. and Svensson, C. (2009) Heifer Rearing Conditions Affect Length of Productive Life in Swedish Dairy Cows. Preventive Veterinary Medicine, 89, 255-264. http://dx.doi.org/10.1016/j.prevetmed.2009.02.012

[8] Cooke, J.S., Cheng, Z., Bourne, N.E. and Wathes, D.C. (2013) Association between Growth Rates, Age at First Calving and Subsequent Fertility, Milk Production and Survival in Holstein-Friesian Heifers. Open Journal of Animal Sciences, 3, 1-12. http://dx.doi.org/10.4236/ojas.2013.31001

[9] Coffey, M.P., Hickey, J. and Brotherstone, S. (2006) Genetic Aspects of Growth of Holstein-Friesian Dairy Cows from Birth to Maturity. Journal of Dairy Science, 89, 322-329. http://dx.doi.org/10.3168/jds.S0022-0302(06)72097-5

[10] Wathes, D.C., Brickell, J.S., Bourne, N.E., Swali, A. and Cheng, Z. (2008) Factors Influencing Heifer Survival and Fertility on Commercial Dairy Farms. Animal, 2, 1135-1143. http://dx.doi.org/10.1017/S1751731108002322

[11] Micke, G., Sullivan, T., Magalhaes, R., Rolls, P., Norman, S. and Perry, V. (2010) Heifer Nutrition during Early- and Mid-Pregnancy Alters Fetal Growth Trajectory and Birth Weight. Animal Reproduction Science, 117, 1-10. http://dx.doi.org/10.1016/j.anireprosci.2009.03.010

[12] Funston, R.N., Larson, D.M. and Vonnahme, K.A. (2010) Effects of Maternal Nutrition on Conceptus Growth and Offspring Performance: Implications for Beef Cattle Production. Journal of Animal Science, 88, 205-215. http://dx.doi.org/10.2527/jas.2009-2351

[13] Long, N.M., Prado-Cooper, M.J., Krehbiel, C.R., DeSilva, U. and Wettemann, R.P. (2010) Effects of Nutrient Restrictions of Bovine Dams during Early Gestation on Postnatal Growth, Carcass and Organ Characteristics and Gene Expression in Adipose Tissue and Muscle. Journal of Animal Science, 88, 3251-3261. http://dx.doi.org/10.2527/jas.2009-2512

[14] Blecha, R., Bull, R.C., Olson, D.P., Ross, R.H. and Curtis, S. (1981) Effects of Prepartum Protein Restriction in the Beef Cow on Immunoglobulin Content in Blood and Colostral Whey and Subsequent Immunoglobulin Absorption by the Neonatal Calf. Journal of Animal Science, 53, 1174-1180.

[15] Arnott, G., Roberts, D., Rooke, J.A., Turner, S.P., Lawrence, A.B. and Rutherford, K.M.D. (2012) The Importance of the Gestation Period for Welfare of Calves: Maternal Stressors and Difficult Births. Journal of Animal Science, 90, 5021-5034. http://dx.doi.org/10.2527/jas.2012-5463

[16] Margerison, J.K. and Downey, N. (2005) Guidelines for Optimal Dairy Heifer Rearing and Herd Performance. Calf and Heifer Rearing: Principles of Rearing the Modern Dairy Heifer from Calf to Calving. 60th University of Nottingham Easter School in Agricultural Science, Nottingham, 23-24 March 2004, 307-338.

[17] Johanson, J.M. and Berger, P.J. (2003) Birthweight as a Predictor of Calving Ease and Perinatal Mortality in Holstein Cattle. Journal of Dairy Science, 86, 3745-3755. http://dx.doi.org/10.3168/jds.S0022-0302(03)73981-2

[18] Lombard, J.E., Garry, F.B., Tomlinson, S.M. and Garber, L.P. (2007) Impacts of Dystocia on Health and Survival of Dairy Calves. Journal of Dairy Science, 90, 1751-1760. http://dx.doi.org/10.3168/jds.2006-295

[19] Zanton, G.I. and Heinrichs, A.J. (2005) Meta-Analysis to Assess Effects of Prepubertal Average Daily Gain of Holstein Heifers on First-Lactation Production. Journal of Dairy Science, 88, 3860-3867. http://dx.doi.org/10.3168/jds.S0022-0302(05)73071-X

[20] Ettema, J.F. and Santos, J.E. (2004) Impact of Age at First Calving on Lactation, Reproduction, Health and Income in First-Parity Holsteins on Commercial Farms. Journal of Dairy Science, 87, 2730-2742. http://dx.doi.org/10.3168/jds.S0022-0302(04)73400-1

[21] Macdonald, K.A., Penno, J.W., Bryant, A.M. and Roche, J.R. (2005) Effect of Feeding Level Pre- and Post-Puberty and Body Weight at First Calving on Growth, Milk Production, and Fertility in Grazing Dairy Cows. Journal of Dairy Science, 88, 3363-3375. http://dx.doi.org/10.3168/jds.S0022-0302(05)73020-4

[22] Sakaguchi, M., Suzuki, T., Sasamoto, Y., Takahashi, Y., Nishiura, A. and Aoki, M. (2005) Effects of First Breeding Age on the Production and Reproduction of Holstein Heifers up to the Third Lactation. Animal Science Journal, 76, 419-426. http://dx.doi.org/10.1111/j.1740-0929.2005.00285.x

[23] Raboisson, D., Delor, F., Cahuzac, E., Gendre, C., Sans, P. and Allaire, G. (2013) Perinatal, Neonatal, and Rearing Period Mortality of Dairy Calves and Replacement Heifers in France. Journal of Dairy Science, 96, 2913-2924. http://dx.doi.org/10.3168/jds.2012-6010 
[24] Menzies, F.D., Bryson, D.G., McCallion, T. and Matthews, D.I. (1996) Mortality in Cattle up to Two Years Old in Northern Ireland during 1992. Veterinary Record, 138, 618-622. http://dx.doi.org/10.1136/vr.138.25.618

[25] Brickell, J.S., McGowan, M.M. and Wathes, D.C. (2010) Association between Neospora caninum Seropositivity and Perinatal Mortality in Dairy Heifers at First Calving. Veterinary Record, 167, 82-85. http://dx.doi.org/10.1136/vr.c3583

[26] Givens, M.D. and Marley, S.D. (2008) Infectious Causes of Embryonic and Fetal Mortality. Theriogenology, 70, 270285. http://dx.doi.org/10.1016/j.theriogenology.2008.04.018

[27] Nickerson, S.C., Owens, W.E. and Boddie, R.L. (1995) Mastitis in Dairy Heifers: Initial Studies on Prevalence and Control. Journal of Dairy Science, 78, 1607-1618. http://dx.doi.org/10.3168/jds.S0022-0302(95)76785-6

[28] Waage, S., Sviland, S. and Ødegaard, S.A. (1998) Identification of Risk Factors for Clinical Mastitis in Dairy Heifers. Journal of Dairy Science, 81, 1275-1284. http://dx.doi.org/10.3168/jds.S0022-0302(98)75689-9

[29] De Vliegher, S., Fox, L.K., Piepers, S., McDougall, S. and Barkema, H.W. (2012) Invited Review: Mastitis in Dairy Heifers: Nature of the Disease, Potential Impact, Prevention and Control. Journal of Dairy Science, 95, 1025-1040. http://dx.doi.org/10.3168/jds.2010-4074

[30] Boulton, A.C., Rushton, J. and Wathes, D.C. (2015) A Study of Dairy Heifer Rearing Practices from Birth to Weaning and Their Associated Costs on UK Dairy Farms. Open Journal of Animal Sciences, 5, 185-197. http://dx.doi.org/10.4236/ojas.2015.52021

[31] Boulton, A.C., Rushton, J. and Wathes, D.C. (2015) The Management and Associated Costs of Rearing Heifers on UK Dairy Farms from Weaning to Conception. Open Journal of Animal Sciences, 5, 294-308. http://dx.doi.org/10.4236/ojas.2015.53034

[32] Jousan, F.D., Drost, M. and Hansen, P.J. (2005) Factors Associated with Early and Mid-to-Late Fetal Loss in Lactating and Non-Lactating Holstein Cattle in a Hot Climate. Journal of Animal Science, 83, 1017-1022.

[33] Agro Business Consultants Ltd. (2013) The Agricultural Budgeting and Costing Book. Agro Business Consultants Ltd., Melton Mowbray.

[34] DairyCo (2011) Grassland Management Improvement Programme. Agriculture and Horticulture Development Board, Stoneleigh.

[35] DairyCo (2012) PD+ Managing Heifer Rearing. Agriculture and Horticulture Development Board, Stoneleigh. http://dairy.ahdb.org.uk/resources-library/technical-information/fertility/pdplus-section-10-managing-heifer-rearing/

[36] Hoffman, P.C. (1997) Optimum Body Size of Holstein Replacement Heifers. Journal of Animal Science, 75, 836-845.

[37] Dohoo, I., Martin, W. and Stryhn, H. (2009) Linear Regression. In: Dohoo, I., Martin, W. and Stryhn, H., Eds., Veterinary Epidemiologic Research, VER Inc., Prince Edward Island, 323-364.

[38] Mohd Nor, N., Steeneveld, W., van Werven, T., Mourits, M.C.M. and Hogeveen, H. (2013) First-Calving Age and First-Lactation Milk Production on Dutch Dairy Farms. Journal of Dairy Science, 96, 981-992. http://dx.doi.org/10.3168/jds.2012-5741

[39] Bach, A. and Ahedo, J. (2008) Record Keeping and Economics of Dairy Heifers. Veterinary Clinics of North America: Food Animal Practice, 24, 117-138. http://dx.doi.org/10.1016/j.cvfa.2007.10.001

[40] Heinrichs, A.J., Jones, C.M., Gray, S.M., Heinrichs, P.A., Cornelisse, S.A. and Goodling, R.C. (2013) Identifying Efficient Dairy Heifer Producers Using Production Costs and Data Envelopment Analysis. Journal of Dairy Science, 96, 1-8. http://dx.doi.org/10.3168/jds.2012-6488

[41] Promar International (2011) What Are Heifer Replacements Really Costing You? http://www.milkminder.co.uk/news/Heifer\%20costs.PDF

[42] Department of Agriculture and Rural Development North Ireland (DARDNI) (2014) Farm Business Data 2014. http://www.dardni.gov.uk/farm_business_data_2014.pdf

[43] McCann, C.M., Baylis, M. and Williams, D.J.L. (2010) Seroprevalence and Spatial Distribution of Fasciola hepatica Infected Dairy Herds in England and Wales. Veterinary Record, 166, 612-617. http://dx.doi.org/10.1136/vr.b4836

[44] Moredun Research Institute (2013) Neospora-A Major Problem for the British Dairy Industry. http://www.checs.co.uk/wp-content/uploads/2014/01/MO2480_NeosporaReport_v6_3001.pdf

[45] Booth, R.E. and Brownlie, J. (2012) Establishing a Pilot Bovine Viral Diarrhoea Virus Eradication Scheme in Somerset. Veterinary Record, 170, 73. http://dx.doi.org/10.1136/vr.100191

[46] Kuhn, M.T., Hutchinson, J.L. and Wiggans, G.R. (2006) Characterization of Holstein Fertility in the United States. Journal of Dairy Science, 89, 4907-4920. http://dx.doi.org/10.3168/jds.S0022-0302(06)72541-3 